\title{
原著論文
}

\author{
続々・咀嚼時, 主機能部位の観察 \\ ーインレー装着歯に起こった歯質の破折との関係一 \\ 加藤 均, 三浦宏之, 長谷川成男*, 吉田惠一, 田中義浩 \\ 東京医科歯科大学大学院 医歯学総合研究科 \\ 口腔機能再構築学系専攻 搑食機能保存学講座 \\ 摄食機能保存学分野, *明倫短期大学 \\ 〔受付：平成14年 9 月 5 日]
}

\section{Observation on the Main Occluding Area in Mastication}

Part III: The Relation between the Main Occluding Area and the Tooth Fracture of the Inlay-restored Tooth

\author{
Hitoshi Kato, Hiroyuki Miura, Shigeo Hasegawa*, Keiichi Yoshida and Yoshihiro Tanaka \\ Graduate School, Tokyo Med. and Dent. Univ., Div. of Oral Health Sciences, \\ Dept. of Restorative Sciences, Fixed Prosthodontics, *Meirin College
}

[Recieved: September 5, 2002.]

Key Word: main occluding area, occlusal surface, mastication, functional cusp, failed inlay

\begin{abstract}
In order to clear the functional force loading on the occlusal surface, we explored the relation between the main occluding area and tooth fracture of an inlay-restored tooth. From the observation of 44 cases the following conclusions were obtained:

1. Tooth fracture of an inlay-restored tooth could be classified into two types: fracture at the margin of the inlay (margin fracture), and fracture extending over the cusp (cusp fracture).

2 . In many cases, tooth fracture occurred at the functional cusp and coincided with the main occluding area; therefore, the main cause of the fracture could be recognized as mastication on the main occluding area.
\end{abstract}

3 . Care must be taken to the main occluding area when restoring.

抄録 機能時に咬合面が受ける力を解明するために, 歯質の破折を惹起したインレー装着歯44症例につい て, 破折状況と主機能部位との位置関係を検討し, 以下の結論を得た。

1.インレー装着歯に起こった歯質の破折は, インレー辺縁に沿った破折, 辺縁破折と咬頭に及んだ破折, 咬頭破折とに大別できる.

2. 多くの症例で歯質の破折は機能咬頭に発生し, 加えて主機能部位と一致していたことから, 破折の主 因は主機能部位としての咀嚼機能によるものと考えられる.

3. 歯冠修復に際しては主機能部位にも考慮を払うことが必要である. 


\section{I. 緒 言}

歯冠修復の大きな目的は歯冠の形態・機能を回復・維 持することにある．著者らは，回復した咬合面にはさま ざまな力が働き，その力の大きさ，方向，作用部位が修 復歯のその後の経過を左右することから，機能時に発生 する力と調和した機能的咬合面形態を求めて, ミク口的 およびマクロ的視点にたっての研究を行ってきだ-9).

ミクロ的視点にたった歯の変位の測定で，上顎大臼柬 は諸機能の中で咀噮時に $150 \mu \mathrm{m}$ 前後と最も大きい舌側へ の変位を示し，咀嚼が歯の機能・機構に大きく関与して いることがわかった3)。そこで，咀嚼時に注目してマク 口的視点での研究を行い，摂取された食物の多くは緊密 な咬合関係にある大臼歯部の機能咬頭間の主機能部位で 粉砕・細分化され ${ }^{7.8)}$, 粉砕・細分化された食物は非機 能咬頭の被蓋に誘導されて煩舌側へ流出することなどを 明らかにした ${ }^{9)}$ 。これらの結果は, 主機能部位が咀嚼時 に中心的役割を担うことによって，咀嚼力の作用点とな り, 常時相当の咀嚼力を受けていることを示唆してい る.

今回は, インレー装着歯に起こる術後のトラブルの多 くは，歯質の破折を伴い，破折部が咬合面内に限局して いることから，これらの症例は機能時に咬合面に作用す る力を解明する上で貴重な情報を含んでいるであろうと 考え，歯質の破折を惹起していた44症例のインレー装着 歯について，主機能部位との関係を中心に検討を行なっ た

\section{II. 観察方法}

\section{1. 症 例}

症例は1993年～2001年の 8 年間に大臼歯部のインレー 装着歯に異常を訴えて東京証券業健康保険組合診療所歯 科を受診した患者の中で，咬合面部に歯質の破折を認め た 44 症例（年齢33.5 65.6歳，平均50.8歳）である。こ れらの症例はインレー装着歯部で，いずれも正常被蓋関 係を示していた。また, 観察した44症例中, 当診療所で 修復した装着日が明確なインレーは1985年〜1998年の13 年間に装着した 38 症例で，いずれも寒天アルジネート法 で印象採得し，12\%金銀パラジウム合金で作製して，リ ン酸亜鉛セメントで合着したものである。

症例はすべて口腔内で写真撮影を行い，歯質の破折状 況, 破折部位と主機能部位との関係, 装着期間について 検討した。なお，インレーが脱落していた場合にはイン レーを窩洞内に戻して確認した。

\section{2. 破折状況の観察}

歯質の破折状況は, インレー辺縁に沿った破折, “辺縁 破折”と，咬頭に及んだ破折，“咬頭破折”に大別し， 破折部位は大臼歯の咬合面を煩舌・近遠心の 4 部位に別 けて検討した。

インレーの装着期間は装着した日からインレーの脱 落，歯質の破折などが発生して患者が受診した日までと した。

\section{3. 主機能部位の決定}

主機能部位 ${ }^{7)}$ の決定には, 直径 $3.4 \mathrm{~mm}$ のストッピン グを長さ䄪 $4 \mathrm{~mm}$ に切断したもの 1 個を患者の舌上に載 せ，咀嚼時を想定させて当該インレー装着歯側の噛みや すい部位で 1 回の噛みしめを行わせた。これを 5 回行わ せ, 噛みしめの結果が集中した部位を主機能部位とし た。

なお，噛みしめられた後のストッピングは直径 $8 \mathrm{~mm}$ 前後であったが，咬合面に広がったストッピングの範囲 内に歯質の破折部が含まれていた場合には，主機能部位 と破折部位が一致するものと判定した。

\section{III. 結 果}

\section{1. 歯質の破折状況}

観察した44症例中，辺縁破折は31症例,咬頭破折は 13 症例であった。また，インレーが脱落していた症例は 29 症例であった。

\section{1) 辺縁破折}

症例 A（図 1-1), B（図 2-1，2）は辺縁破折の 代表例で，症例 Bでは脱落したインレーを窩洞内に戻す とインレー辺縁部の歯質の破折が明確になる。症例 $\mathrm{A} の$ 破折部には食物残渣の圧入と二次う蝕が，症例 Bではイ ンレーが脱落した窩洞の機能咬頭部に限局して二次う蝕 がみられ，辺縁破折症例ではほとんどの場合に二次う蝕 が認められた。

辺縁破折は上顎蒾で20症例，下顎歯で11症例で，破折 部位はいずれも機能咬頭の内斜面にあった。非機能咬頭 の内斜面での辺縁破折はみられなかった（表 1 ).

\section{2 ) 咬頭破折}

症例 C（図 3-1），D（図 4）は咬頭破折の代表例 で, 症例 Cでは機能咬頭が, 症例 Dでは非機能咬頭が破 折している。症例 C, D ともに破折部に二次う蝕は認め られないが，他の咬頭破折の症例でも二次う蝕は認めら れなかった。

咬頭破折は上顎歯で 3 症例，下顎歯で10症例であった が，舌側咬頭が破折した下顎歯の 5 症例を除いた 8 症例 


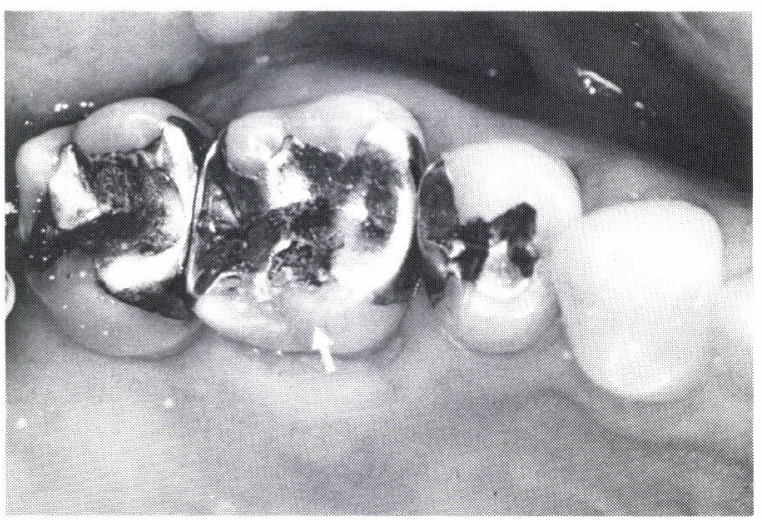

1-1

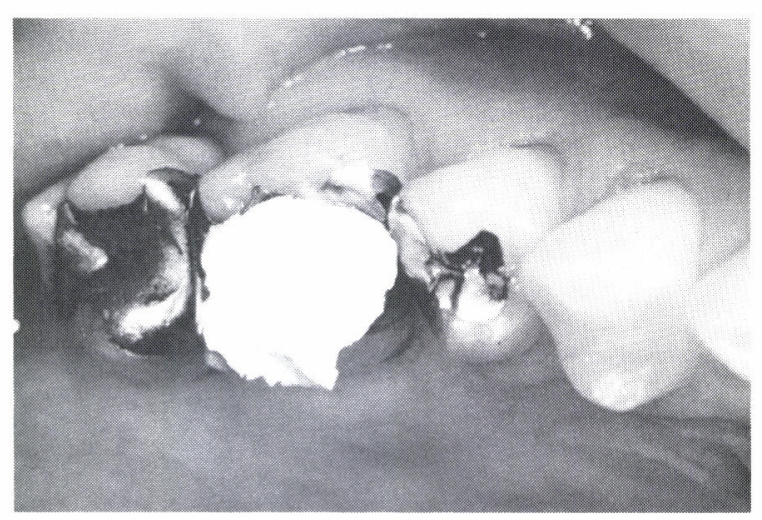

$1-2$

図 1 症例 A（辺縁破折例）

1-1：機能咬頭内斜面部の辺縁歯質が 破折している.

1-2 : 破折部は主機能部位と一致する.

Fig. 1 Case A (Case of margin fracture)

1-1: The tooth substance at the margin of the inlay fracture in the inner incline of the functional cusp.

$1-2$ : The fracture is coincident with the main occluding area.
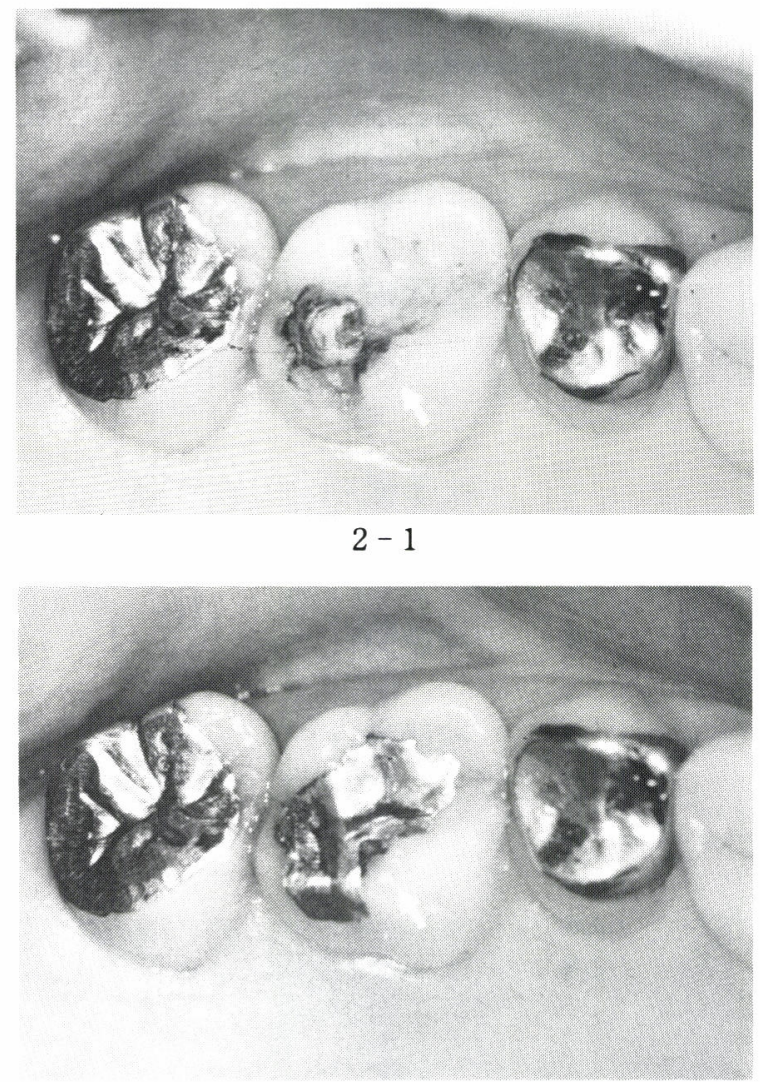

$$
2-2
$$

図 2 症例 $\mathrm{B}$ (辺縁破折例)

2-1：インレ-脱落後の窩洞。機能咬頭 部に二次カリエスが発生している. 2-2：䆟洞内に脱落インレーを試適. 機能咬頭部の辺縁歯質が破折している.

Fig. 2 Case B (Case of margin fracture)

2-1: The cavity after failure of the inlay. Secondary caries is observed at the functional cusp.

$2-2$ : The failed inlay is fitted into the cavity. The tooth fracture at the margin of the inlay is at the functional cusp.
で, 破折部位は機能咬頭にあった。なお, 上顎煩側咬頭 の咬頭破折症例は 1 症例もみられなかった（表 1 )。

\section{2. 破折部位の分布}

辺縁破折と咬頭破折を合わせたインレー装着歯の歯質 の破折は，上顎第一大臼歯で16症例と最も多く，下顎第 一大臼歯の14症例がこれに続き，上顎第二大臼歯では 7 症例, 下顎第二大臼歯では 6 症例であった（図 5 , 表 1 ).

辺縁破折の部位別では上顎第 1 大白歯の近心舌側部の
9 症例が最も多く, ついで下顎第 1 大白歯の遠心㚘頁側部 の 7 症例となっていた (図 5 ). しかし,これらの部位 に咬頭破折は 1 症例もなかった。

咬頭破折の部位別では下顎第 1 大臼歯の近心㚘側部の 4 症例が最も多く，ついで上顎第 1 大兒歯の遠心舌側部 の 3 症例となっていた (図 5 ). なお,これらの部位に は辺縁破折もみられた。

\section{3. 装着期間}

装着日が明確なインレーの平均装着期間は 6 年 5 ケ月 
表 1 歯質の破折状況

Table 1 The condition of the tooth fracture. ( )is the number of discordant cases with the main occluding area.
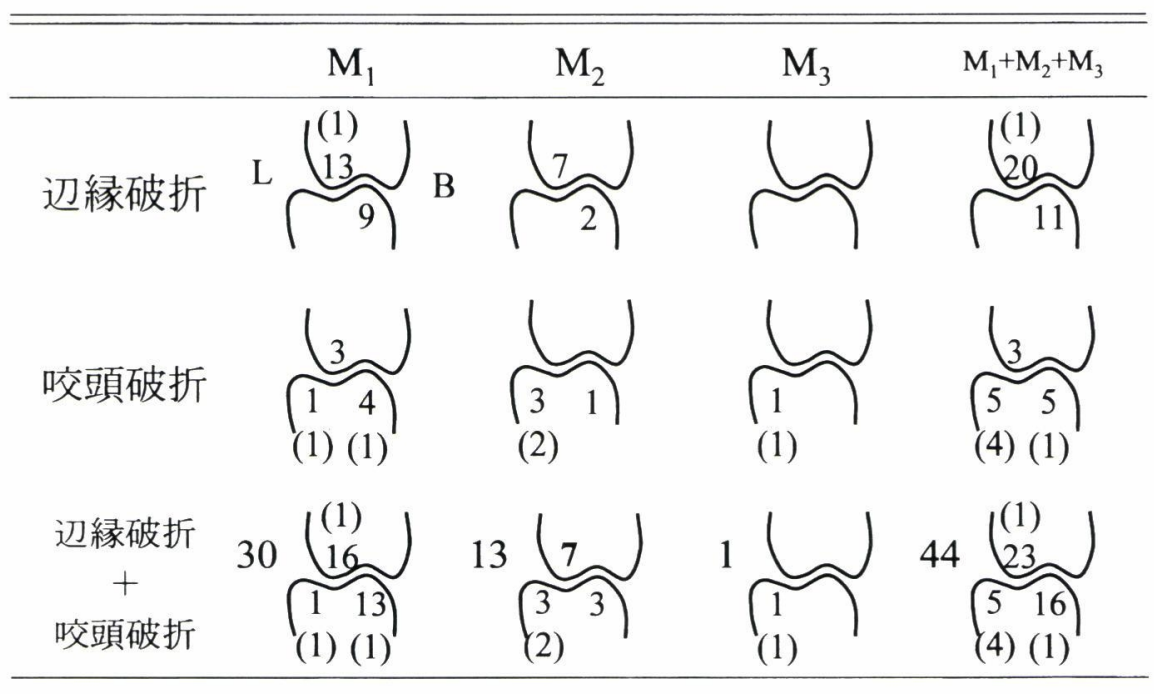

( ) 内は主機能部位との不一致数
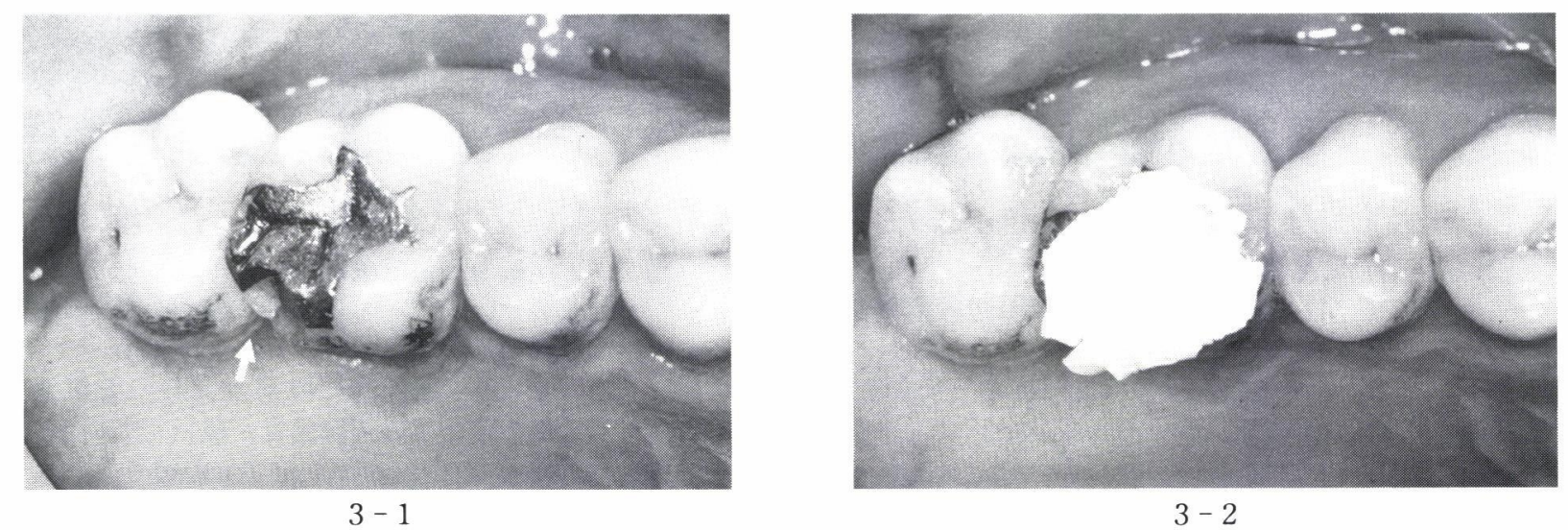

図 3 症例 C（咬頭破折例）

3-1：破折は機能咬頭の一部にまで及んでいる.

$3-2$ : 破折部は主機能部位と一致する。

Fig. 3 Case $\mathrm{C}$ (Case of cusp fracture)

$3-1$ : The tooth fracture extends over the functional cusp.

$3-2$ : The tooth fracture is coincident with the main occluding area.

（10ケ月～13年 3 ケ月）であった。辺縁破折の症例数は 装着 2 年目から次第に増加し, 6 年目で 5 症例となって ピークを迎え，その後は次第に減少する傾向にあった (図6).

一方，咬頭破折は 7 年目に最多の 4 症例を示したが, 1 年目の 2 症例から始まってランダムに発生する傾向が あった(図6)。

\section{4. 主機能部位}

主機能部位 ${ }^{7)}$ は, 歯質の破折が起こったインレー装 着茵を含む上顎あるいは下顎の歯列で表現すると ${ }^{7)}$, 下 顎第 2 大鼠歯中央部を示した 1 症例を除いた 43 症例で, 機能咬頭内斜面部に限局して存在していた（図 $1-2$, 図 3-2, 図 4, 図 7). 歯種別では44症例中, 上下顎 合わせて第 1 大臼歯部が 24 症例と最も多く, ついで第 2 大臼歯部の 13 症例，第 1 . 第 2 大臼歯歯間部の 7 症例で 


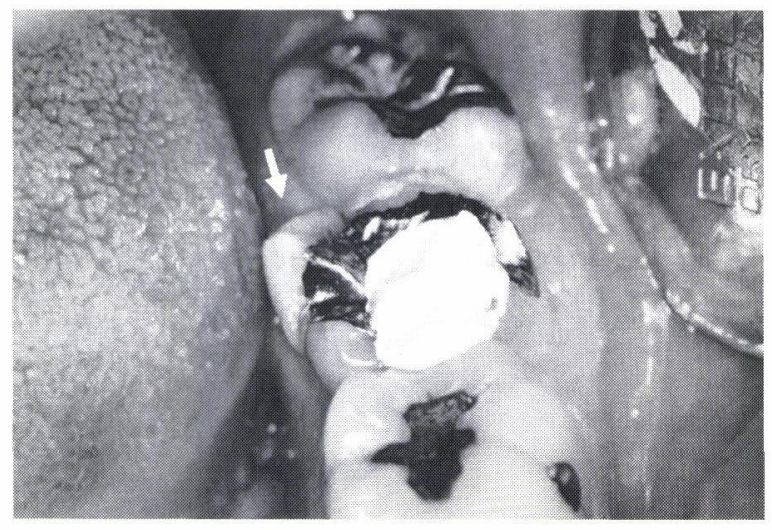

図 4 症例 D（咬頭破折例）

破折は下顎舌側咬頭に及んでいるが，破 折部は主機能部位と一致しない。

Fig. 4 Case D (Case of cusp fracture)

The fracture extends to the lingual cusp of lower molar. The fracture is not coincident with the main occluding area.

\section{あった（図 7 ).}

辺縁破折では31症例中の30症例の破折部位が主機能部 位と一致し，咬頭破折では13症例中， 8 症例の破折部位 が主機能部位と一致していた。一方，破折部位が主機能
部位と一致していなかった辺縁破折 1 症例および咬頭破 折 5 症例の主機能部位は, 当該インレー装着歯あるいは その隣在蒾の機能咬頭内にあった（図 5 ).

\section{N. 考察}

う蝕に罹患した歯はその後幾度となく修復が重ねら れ，最悪の場合には变失にまでいたるということが，従 来から指摘されている ${ }^{10)}$.

そして今，歯冠修復の目的にもあるように，修復され た歯の形態，機能を長く維持し，口腔機能を保全するこ とが歯科学での重要な課題となっている，再修復の原因 に関しては多くの研究が行われ，その主因としては辺縁 漏洩 $^{11)}$, 咬合接触による辺縁歯質の破折 ${ }^{12.13)}$ などが報 告されている.

著者らは臨床において遭遇するさまざまな歯質の破折 を起こしたインレー装着歯を詳細に観察して, 咀嚼機能, ことに主機能部位との関連性も無視できないとの示唆を 得たので, 以下のような検討, 考察を行った.

\section{1.インレー辺縁部の歯質の破折}

インレー装着歯に起こる辺縁歯質の破折は, 日常の機 能時に作用する力が原因となる可能性がある.

本研究におけるインレー辺縁部の歯質の破折は, すべ

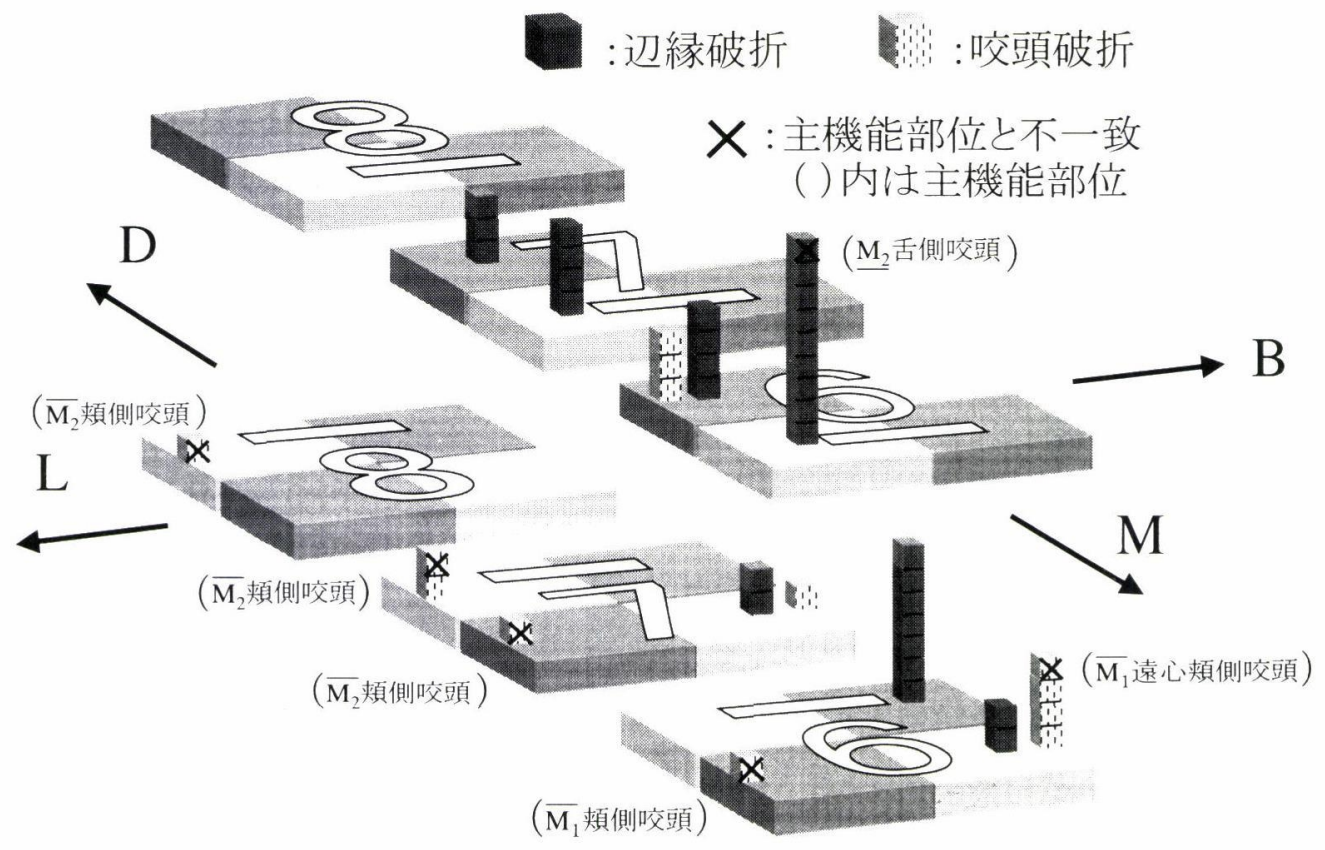

図 5 破折部位の歯種別分布状況

Fig. 5 Distribution of the fracture on each molar. 


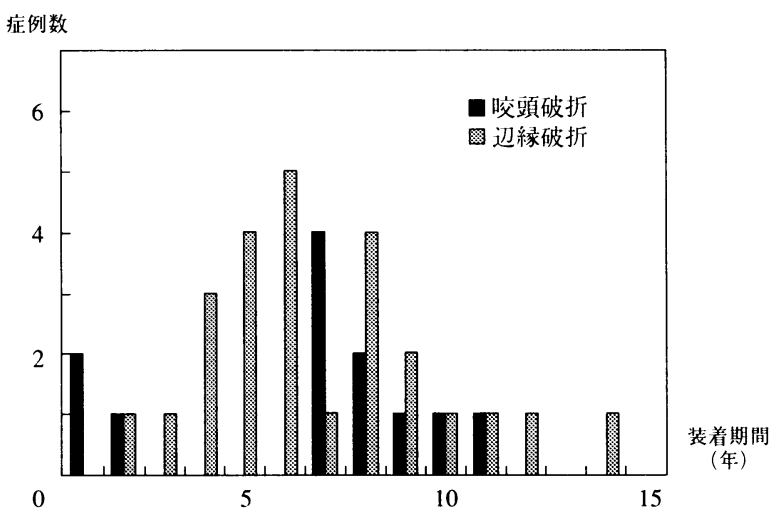

図 6 装着期間と歯質の破折の関係

Fig. 6 Relation between the number of the tooth fracture and the term of restoration.

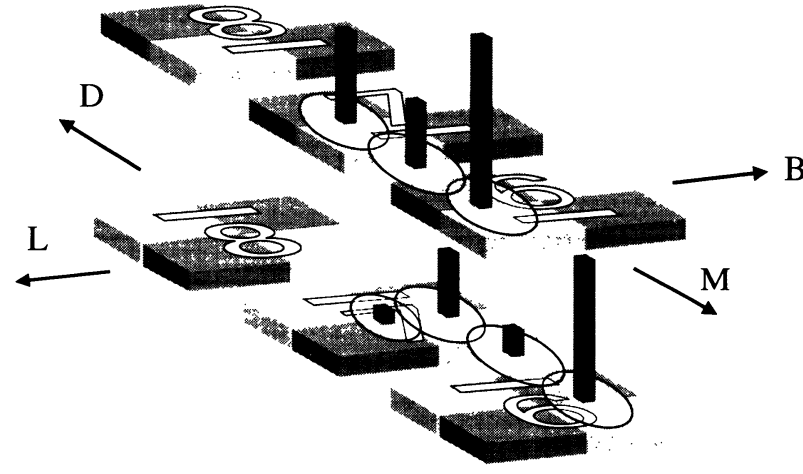

図 7 主機能部位の分布状況

Fig. 7 Distribution of the main occluding area.

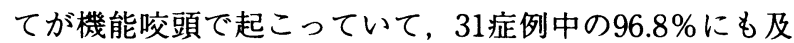
ぶ30症例で破折部位が主機能部位と一致していた（表 1).これらの結果は, 破折が咀嚼によって起こったこ とを示すとともに，繰り返し同部位で咀嚼するという主 機能部位の存在をも明らかにしている。また，咬頭嵌合 位において緊密な咬合関係にある主機能部位に歯質の破 折が多く惹起されていたことは，ミクロ的研究によって 明らかとなった咀嚼ストロークの各終末位付近で咀嚼力 が最大となる ${ }^{5.6)}$ ということが，大きく関与している ものと考えられる.

さらに，インレーの脱落を伴った症例において辺縁破 折部に限局した二次う蝕が多数例で認められたことは, これらの二次う蝕が辺縁漏洩によるものではなく，はじ めに破折が起こり，ついで食物が押し込まれ，同部が食 物残査の貯溜域となった結果として生じたことを示して いる.

辺縁破折の症例数が装着期間とともに増加し，6年目 でピークを迎えていたことは（図6），辺縁破折が偶発 的に起こったものではなく，インレー装着後に同部が日 常の咀嚼の主機能部位となって機能したことによる歯質 の疲労の限界が, 多くの症例で 6 年目前後に訪れるもの として考えることができる。

他方，辺縁破折が非機能咬頭の内斜面部にみられなか ったことは, 主機能部位が機能咬頭内斜面部に限局され ていること ${ }^{7)}$ を示すとともに，非機能咬頭は粉砕・細 分化された食物を煩舌側へ誘導するという役割を演じて はいるものの $\left.{ }^{9}\right)$, 内斜面部は粉砕・細分化には直接関与 することなく，破折にいたるほどの咀嚼力を受けていな いことを示している.

\section{2. 咬頭に及ぶ破折}

咬頭破折症例は機能咬頭に 8 症例みられたが, 主機能 部位と一致しない下顎舌側咬頭にも5 症例がみられた (表 1)。これは咀嚼の初期などに咬合面上に大きな食物 が載り，主機能部位を越えて広範な部位で粉砕が行われ たときに起こるもので，下顎舌側咬頭が鋭くそびえ立つ

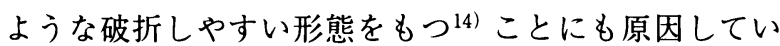
ると考えられる。また，咬頭破折が装着期間に関わらず ランダムに発生していることは（図6），これらが偶発 的に加わった過大な咀嚼力による，事故的な状況下で起 こっていた可能性を示している. したがって，インレー 装着歯での咬頭破折と辺縁破折は異なる原因で起こるも のと考えられる.

なお，上顎煩側咬頭部には辺縁破折，咬頭破折がとも にみられなかったが（図 5 )，これは同部が咀嚼のごく 初期を除いては食物の粉砕・細分化に関与することが少 なく，破折にいたるほどの力を受けることは稀であるこ とを示すものである.

\section{3. 破折菌種}

歯種別に辺縁破折と咬頭破折を合計した症例数は，上 下顎第一大臼歯で最も多く 44 症例中の30症例で, 68 . $1 \%$ あ゙あった（表 1 ).

これらの症例の修復が多く行われた1989年〜1995年の 7 年間の各年毎に，装着年毎のインレーの歯種別総数に 対する，歯質の破折が発生したインレー装着歯数の比率 を求めると，第一大臼歯で $5.2 \%$ ，第二大臼歯で $1.8 \%$, 第三大臼歯で $1.3 \%$ となり，第一大臼歯で比率は最も高 く $3 \sim 4$ 倍を示した (表 $2 ， 3)$. すなわち, 本観察で 第一大曰歯での破折症例が多かったことは, 装着したイ 
表 2 インレー装着歯数と歯質破折発生歯数 (1989～1995年)

Table 2 The relation between the number of restorations and fractured teeth (1989 1995).

\begin{tabular}{|c|c|c|c|c|c|c|c|}
\hline$\underbrace{\text { 装着年 }}_{\text {菊種 }}$ & '89 & '90 & '91 & '92 & '93 & '94 & '95 \\
\hline $\mathrm{M}_{1}$ & & & & & & & \\
\hline$M_{2}$ & & & & & & & 25 \\
\hline $\mathrm{M}_{3}$ & & & 0 & 0 & & & $0 / 12$ \\
\hline
\end{tabular}

ンレーの総数が多かったことによるものではなく，主機 能部位が同部に集中していたこと（図 7 ）に原因するも のと考えられる。

\section{4. 主機能部位}

本観察44症例の主機能部位は, 43症例が機能咬頭内に あって，歯間部も含めると $70.5 \%$ が第 1 大臼歯に存在し， 従来の報告 ${ }^{7)}$ ともほほ一致していたことから，主機能 部位の多くが上下顎第 1 大臼歯の機能咬頭間に存在する ことがさらに明確になった。

辺縁破折の31症例中の30症例, $96.8 \%$ で歯質の破折部 位と主機能部位が一致していた（表 1 , 図 5 ).このこ とは，主機能部位が咀嚼時に中心となり，繰り返し咀嚼 圧を受けていることを示すものであり, 非機能咬頭に辺 縁破折がみられなかったことは逆の面から主機能部位の 存在を裏付けるものである. Shiau らは, 砂糖や寒天を 球状に加工した試験食品を 13 人の被験者に咀嚼させ, $\mathrm{X}$ 線透視法を用いて観察した結果，多くの場合に粉砕は第 1 大臼歯部で行われていることを明らかにしている15). この報告も，主機能部位が多くの被験者で第 1 大臼歯部 にあることを示唆するものであろう.

また，辺縁破折の多発部位は，上顎では第 1 大臼歯近 心舌側部の 9 症例, 下顎では第 1 大臼歯遠心煩側部の 7 症例で，アングル 1 級の咬合関係にある上下顎大臼歯間 の対合関係では同部が最も緊密に咬合する部位，主機能 部位となっていることが多い7.16)こととも一致してい る。

咬頭破折は，非機能咬頭である下顎舌側咬頭にもみら れ，主機能部位と無関係のようにも考えられるが，咀嚼 の初期には食物が大きく主機能部位を超えての拡がりを もつので, 主機能部位で咀嚼されても時として非機能咬
表 3 歯種別の歯質破折発生率（1989～1995 年)

Table 3 The rate of the fractured tooth to the restoration on each molar $(1989 \sim 1995)$.

\begin{tabular}{ccc}
\hline \hline & \begin{tabular}{c} 
歯質破折歯数 \\
\cline { 2 - 2 }
\end{tabular} & 将レー装質破折発生率 \\
\hline $\mathrm{M}_{1}$ & $22 / 427$ & $5.15 \%$ \\
$\mathrm{M}_{2}$ & $8 / 439$ & $1.82 \%$ \\
$\mathrm{M}_{3}$ & $1 / 75$ & $1.33 \%$ \\
\hline
\end{tabular}

頭の破折を招くことがあると考えることができる。この ことは, 咬頭破折13症例中主機能部位と一致するもの 8 症例, 主機能部位に近接する歯の破折が 4 症例という結 果からも導かれる（図 5 , 表 1 )。なお, 非機能咬頭の 咬頭破折が下顎舌側咬頭にはみられたが，上顎煩側咬頭 にみられなかったのは，前述のような上下顎大臼柬部の 咬頭の形態的な相違 ${ }^{14)}$ によるものと考えられる.

以上のことから，インレー装着後の経過と主機能部位 の間には密接な関係が認められ，歯冠修復に際しては主 機能部位にも十分な考慮を払うことの必要性 ${ }^{17)}$ が示唆 された。

\section{V. 結 論}

大臼歯部のインレー装着歯に起こった歯質の破折症 例，44例について主機能部位との関係を検討し，以下の 結論を得た。

1.インレー装着歯に起こった歯質の破折は, インレー 辺縁に沿った破折，辺縁破折と咬頭に及んだ破折，咬 頭破折とに大別できる。

2. 歯質の破折は機能咬頭に発生し, 加えて主機能部位 と一致する症例が多かった。

3. 歯冠修復に際しては主機能部位にも考慮を払うこと が必要である。

\section{V. 文 献}

1) 長谷川成男：咬合学序説一機能的咬合面形態を求め $\tau-$, 医歯薬出版, 東京：1-265, 1988.

2 ) 加藤 均：歯周組織の機能状態に関する研究, 第 1 
報 2 次元微小変位計，補緅誌，25：733-745, 1981.

3 ）加藤 均：歯周組織の機能状態に関する研究，第 2 報 曰歯の機能時の変位と安静時の脈動, 補綴誌, $26: 133-147,1982$.

4 ）加藤 均, 佐藤尚弘, 三浦宏之ほか：咀嚼時におけ る大臼歯の変位と下顎運動, EMGの同時測定, 下 顎運動機能と $\mathrm{EMG}$ 論文集, 昭和58年度：93-98, 1984.

5 ) 加藤 均, 佐藤尚弘, 三浦宏之ほか：多現象同時測 定による咀嚼運動の解析法, 補綴誌, $28: 836-843$, 1884.

6 ) 田中義浩：多变量測定による咀嚼粉砕機能の評価, 第 1 報 顎位間筋電図による咀嚼の観察, 口病誌, $66: 351-360,1999$.

7 ) 加藤 均, 古木 譲, 長谷川成男: 咀嚼時, 主機能 部位の観察，顎機能誌， $2: 119-127,1996$.

8 ）加藤 均, 長谷川成男, 吉田惠一ほか：続・咀嚼時, 主機能部位の観察 - 食片圧入との関係一, 顎機能 誌, 5 ：125-133, 1999.

9 ）加藤 均, 田中義浩, 野澤賢之ほか：咀嚼時, 食物
動態の観察, 顎機能誌, $7: 81-89,2001$.

10）福島正義：修復物の寿命，歯科ジャーナル，36： 697-705, 1992

11）豊島義博：歯を守るための治療と修復，補称臨床 別冊, 35-42, 1997.

12）鈴木祐司：メタルインレーを“長持ち”させるため に，デンタルダイヤモンド，20（8），54-57, 1995.

13）鈴木祐司ほか：インレーの予後を検討する，歯界展 望, 89（4)，789-823, 1997

14）吉田美子：口腔解剖学提要・歯の編, 東京, 1978 , 金原出版, 東京：10-156, 1978.

15) Shau, Y.Y., Chang, H.F., Chang, Y.G., et al.: Observation of bolus position with stadardized test foods and fluoroscopic technique. J. Oral Rehabili. 23: 607-614, 1996

16）三好礼子：内外および近遠心方向から 6 分類した臼 歯部咬合小面の咀嚼運動時の咬合接触, 補緅誌, $46: 203-212,2002$.

17）吉田恵一, 加藤 均, 田中正信ほか：歯をまもる 医歯薬出版, 東京: 97-103, 2002. 